\title{
An Era of Climax of Cordiality in Sino-Pakistan Relations
}

\author{
Manzoor Khan Afridi ${ }^{1}$ \\ ${ }^{1}$ Head of Department of Politics and International Relations International Islamic University, Islamabad-Pakistan \\ Correspondence: Manzoor Khan Afridi, Head of Department of Politics and International Relations International \\ Islamic University, Islamabad-Pakistan.
}

Received: March 27, 2015

doi:10.11114/ijsss.v3i3.759

\author{
Accepted: April 9, 2015 \\ Available online: April 10, 2015
}

URL: http://dx.doi.org/10.11114/ijsss.v3i3.759

\begin{abstract}
The paper seeks to analyze the developments between China and Pakistan since the end of Indo-Pakistan war of 1965 to 1971. After the signing of Pakistan's boundary, air and trade agreements with China, the latter continued its support to Pakistan. Their bilateral relations reached to the climax of cordiality by the exchange official visits of both leaderships and support to each other's key issues and interests. Pakistan changed its pro-West policy of casting vote in favor of Taiwan and against of China for membership in United Nations. Chinese assistance for Pakistan's defense sector began and supported the Pakistan's view regarding the disputed area of Kashmir. However it was Pakistan's start of good relations with the Soviet Union which created a doubt in China's mind after the Tashkent Conference. It was natural for China to express her surprise on the new bilateral relationship between Pakistan and Soviet Union and called it superpowers' conspiracy. The paper concludes that bilateralism in Pakistan's foreign policy brought China and the US to normalization of relations where Pakistan played a bridge role between the two.
\end{abstract}

Keywords: Pakistan, China, United States, SEATO, CENTO

\section{Introduction}

During the period, Pakistan continued its heart-touched relations with China and also its balanced policy of improvements with the Soviet Union and United States. China too adhered to its strategy of dual opposition to the superpowers and India, until her normalization of relations with the US. An important dimension of their relations was the US' not too rigid attitude towards Pakistan for the latter's entente with PRC. It was due to the reason that US and PRC were thinking for rapprochement which came into being with the special role played by Pakistan. Their normalization of relations and Sino-Pakistan entente cordiale led India and the Soviet to sign their friendship treaty in August 1971. "The impending rapprochement may have precipitated or accelerated the U.S.S.R.-Indian friendship treaty and contributed independently to deterioration of relations between the U.S. and India. After all, President Nixon had visited India's most-feared enemy, China, following a Kissinger trip facilitated by the good offices of India's most immediate enemy, Pakistan" (Overholt, 1973).

The persistent not-satisfactory security environment in the form of continued Indo-Pakistan rivalry, strategic thinking about the policies of the superpowers towards the region and unresolved Sino-Indian differences led Pakistan and China once again to forge their cordiality. The alignments and readjustment policies of these states made the situation of the subcontinent more complicated. Pakistan's relations with the Soviet Union improved but with the normalization of US-PRC relations and war of 1971, USSR's breakthrough with Pakistan and Indian ties with the US suffered. At one time, India was playing a double-aligned game to get assistance from the two superpowers against any future Sino-Indian clash, as before she had received a huge amount of aid from the US, USSR and other Communist states of Eastern Europe (Stein, 1967). This was totally unacceptable for China and Pakistan.

The era also saw some negative trends between the two countries when China showed her displeasure about the Tashkent Agreement and Pakistan's cementing ties with the Soviet Union. But notwithstanding these strains, the Sino-Pakistan relations entered into a new phase by cooperation in military and economic fields. With the weakness caused by the war with India and the US cut off supply of aid, resulted in the Pakistan's more dependence on China. "China was the most frustrated of all those who had something to do with the September war. China's frustration had two considerations. Firstly, Chinese ultimata and threats to India during the war, her troop movements and pressure on the Sino-Indian border thereafter, aimed at strengthening Pakistan's position and obtaining concessions for her. Secondly, China had always viewed superpower détente in South Asia and their consensus on closer Indo-Pakistan 
relations, prejudicial to its interests. Therefore, the Tashkent Declaration, which set forth such a policy agreement, was hardly a welcome development for China" (Singh, 1987).

A number of visits exchanged between China and Pakistan. "Military assistance from China brought T-59 tanks, and perhaps forty MIG-19 jet interceptors....In that period, the Pakistanis sought to walk a three-cornered tight rope - they wanted to dramatize a Chinese "presence" in order, as they saw it, to improve their position vis-à-vis their immediate and massive neighbor, India. At the same time, they needed continued American and Western economic assistance, and sought to retain access to American and Western spares and replacements for their depleted army and air force" (Wriggins, 1970).

The earlier phase of their bilateral relations was witnessed for China's effort to boost Pakistan and restrain the United States from going ahead with lavish assistance to India. In this episode, China worked on its previous policy with the alteration of the US for USSR, to get away the latter from going too close to India. Thus as usual, the positive trend prevailed over the negative.

The domestic conditions in both countries like the Cultural Revolution in China, the exit of Z.A. Bhutto from the Ayub's Cabinet and political crisis didn't affect their bilateral relations. Both the countries expressed identical views on regional and international issues. Pakistan continued her support for One China policy and the latter's representation in the UN, while China was going ahead to support Pakistan on the dispute of Kashmir and her other disputes with India. To get answers for the above-stated discussion, with addition of some questions in mind the following two main questions are attempted.

1. How did Pakistan play a role in the Sino-American détente?

2. How China helped Pakistan militarily and politically?

\section{China's Full Assistance Begins}

The balance of threat perception motivated China and Pakistan for strong defense cooperation. It was due to the reason that India had considered China "as the bigger but long-term threat" and Pakistan "as the more active and immediate one" (Mukerjee, 1968). With the war-torn situation, Pakistan was faced with immediate need of strong defense and economy. The need for such policy became cornerstone of Pakistan's interactions with other powers after the United States' imposed embargo of 8 September 1965 on the sale of military hardware and spare parts, which was lasted for three years. The ban on US' supply of arms was more harmful to Pakistan than India. The US termination of its delivery of military equipments to Pakistan came at a time when the latter was struggling for its survival against the aggressor which was five times bigger than its own size. The United States was morally responsible to assist Pakistan against the Indian aggression. "But the United States did just the opposite". Indian military was in advantage against Pakistan in Kashmir sector, backed by the already US' ammunition of the 1962 Sino-Indian border war. If the United States and other members of CENTO and SEATO were not ready to help Pakistan in war, the embargo was totally a "punitive action" against an allied state. It is crystal clear that up to the point, SEATO and CENTO did not provide "genuine security to Pakistan, despite the military assistance, it was considered that the disadvantages of alignment outweighed the advantages" (Bhutto, 1972). The United States ignored its ally, Pakistan and was engaged in Vietnam. Thus the US and other Western nations failed to their earlier commitments to protect the Pakistan's sovereignty. Experienced with all these developments about the failure of alliance members to help militarily and politically (Duffy, 1967), Pakistan since 1966, refrained from participating in the SEATO foreign ministers conferences.

Considering the still-worse security surroundings, once again Pakistan looked towards its real friend, China. Because, small states are more dependent on supplier power for help in the time of an external threat (Paul, 1992). In fact "unlike Pakistan's former western allies (France, U.K. and the US) who repeatedly imposed arms embargoes during Pakistan's wars with India and latterly, when the armed forces took over the country, or Moscow (which later signed a Treaty of Friendship, Peace and Cooperation with New Delhi), China was the only state which continuously provided Pakistan military supplies and did not back out in difficult times. In fact, there was an impressive increase in China's weapons supplies to Pakistan during the wars of 1965 and 1971" (Singh, 1999). From 1965, Pakistan too vehemently sponsored the People's Republic of China's membership in United Nations.

Since the settlement of their boundary agreement, China and Pakistan had signed various agreements. Now the time was ripe for their close cooperation in defense sector, a field for which their friendship is well-known to all. It is believed that the first defense agreement between the two countries was concluded in the end of 1965 . The world came to know at the occasion of Pakistan's National Day celebrations on 23 March 1966 when the newly trained Pakistani pilots flew four Chinese-made MiG-19 jets. The Chinese-supplied T-59 tanks were also present at the moment. By May 1966, the reports came to surface about the Pakistan's acquisition of 3000 assault guns, 100 mortars, 5 T-59 MBTs, 40-60 MiG-19s and 10 IL-28 bombers from China. By the time, about 150 Pakistani pilots were already trained in China to fly 
MiG-19s successfully (Das, 1972). During the Liu Shaoqi's visit to Pakistan at the end of March 1966, Beijing offered $\$ 100$ million interest free loan for enabling Pakistan to purchase weapons from the open market (Singh, 1987). China was worried over the Soviet penetration in Pakistan after the Tashkent Declaration when the USSR was ready to supply arms to Pakistan. In this regard, the first agreement was signed in July 1966 for $\$ 120$ million. India believed that by August 1966 China had already supplied 200 tanks, equipment for two divisions, two squadrons of MiG-19s, and some bombers (Barnds, 1972).

China was not only helping Pakistan by giving her military-needed stuff but also wanted the latter to become self-sufficient in defense production. By this policy, obviously, Beijing's effort was to pull away Islamabad from the superpowers' orbit. "The Sino-Pakistani joint ventures in defense production started with the setting up of a factory for the production of assault rifles at Ghazipur in East Pakistan. The contracts for this had been concluded by the middle of 1967, but were not made public until June 1968. The factory became operational in April 1970. Later, China also provided technical and financial assistance for setting up another ordnance factory near Dhaka" (Singh, 1999). The Indian factor was dominant to push such motives. The eastern wing of Pakistan was more vulnerable to Indian aggression than its western wing because, its three sides were surrounded by India. The Indian threat about the possible attack on East Pakistan in the war of 1965 was still looming in the minds of Pakistani and Chinese policy makers. Because of its geographical proximity, any volatile situation could cause danger for China's Tibet region.

In South Asia, Pakistan is as dear to Beijing's national security interests as Israel is to Washington in Middle-East (Ashraf, 2008). Pakistan could better serve Chinese interests. Keeping in mind the geographical factor and difficulty in help through air, Chinese and Pakistani strategists came to a conclusion for a land contact. It is believed that the 1300 $\mathrm{km}$ long Karakoram Highway was under discussion and the two countries were reached for its construction during the Zhou En-lai's visit to Pakistan in February 1964. But it was during the Liu Shaoqi's visit when the agreement for a Friendship Highway concluded. The road connected two sensitive areas, Xinjiang and Northern Areas of Pakistan. The 1965 war greatly influenced the construction of such a road. If there was a road link between them, Pakistan could get Chinese assistance easily. The road also had a strategic value for China to serve as a bridge between itself and Middle-East and later during the Sino-Soviet clashes could serve as an alternative when her border with the Soviet was closed. Like at the conclusion of Sino-Pakistan Boundary Agreement, India protested on this construction project as well (Ram, 1978).

Willem Van Kemenade has rightly reflected the Indian attitude by saying: "In 1969 India became alarmed again about a planned new land link from Kashgar in Xinjiang to Gilgit in the north-east of Kashmir, the so-called Karakoram Highway, at an altitude of 4,877 meters the highest paved road in the world. This was clearly the first stage in China's 'Long March South' to the Indian Ocean. India calls 'Pakistan Occupied Kashmir' (POK) and Pakistan refers to as the 'Northern Areas'. India considered this a new strategic route that should facilitate Chinese intervention in an inevitable new Indo-Pakistani, be it over Kashmir or over the survival of Pakistan as a geographically anomalous, bipartite country, split by 1,600 kilometers of Indian territory" (Kemenade, 2008).

The Indo-Pakistan hostility could not provide viable circumstances for both superpowers to bring about a common front of India and Pakistan against China, as the United States was willing for a joint defense of the subcontinent at the end of 1950s. The American wish did not materialize when the two giants of South Asia went to war in 1965 and finished any hope for near future's normalization of relations. The Soviet Union too emphasized the importance of the Collective Security System in Asia and wanted to incorporate India and Pakistan together in it. The failure of these schemes provided opportunity for China to use Pakistan as a challenging power for India and by doing so, the US and USSR had not been able to get a strong foothold in subcontinent against China (Brands, 1975). Considering the relative power and relative risk perceptions, the Chinese parity with superpowers and Pakistan's with India intensified the military cooperation. In 1970 Ashok Kapur argued: "Military doctrine consists of a set of principles which evaluate the nature of the threat and proposes an adequate response" (Kapur, 1970). The Indo-Pakistan war proved a threatening behavior of India against Pakistan. It was also an alarming signal for India's second confrontation with China. Thus in addition with political support, the defense assistance boosted the Pakistan's position vis-à-vis India, and China carried on her policy on the same lines of thinking.

\section{Soviets-Pakistan Relations and China}

With the continuation of bilateralism and balanced policy, Pakistan was willing not to antagonize the Soviet Union for the pleasure of United States. Soviet Union was also on the way to balance its strategy between India and Pakistan and not to disappoint an important country in South Asia for the sake of India. Although the Soviet-Pakistan relations were faced with stresses and strains, the decade of sixties experienced an upward move in their ties. However, the President Ayub's visit to Moscow in April 1965 was crucial in terms that the Soviet adopted almost an even-handed policy towards the subcontinent's two major players. Apart from this, the USSR had an ambition to control the Chinese 
influence by the latter's growing relationship with Pakistan. It was also the Soviet thinking that by moving closer to Pakistan, the Pakistan-American alliance would be ineffective (Rajput, 1973). The USSR wanted to hunt two preys by one arrow.

Another development was the Tashkent Declaration in January 1966 when Moscow invited both Islamabad and New Delhi to Tashkent for talks on war-related issues and future peace. Pakistani President Muhammad Ayub Khan and Indian Prime Minister Lal Bahadur Shastri attended the meeting with Soviet Premier Alexey Kosygin. The two leaders decided about the settlement of disputes between India and Pakistan and for maintenance of peace. They agreed to armed forces would be placed on positions they held prior to 5 August 1965. The Soviet interest in the Tashkent Declaration stemmed from the 'isolation of China' rather than to bring India and Pakistan together. If the two countries remained peaceful, it could diminish the Indian need for the Soviet political and military support (Kapur, 1972). As the Soviet strategy was against China, clearly the latter did not welcome Pakistan's closeness with the former. To improve her image among the Asian countries, since 1965, the Soviet Union rushed financial and technical assistance to Pakistan. Soviet had provided a total eighty-one million dollars to Pakistan, by June 1966. The high-level visits also exchanged between the two countries. President Ayub visited Moscow for the third time in 1967. It was followed by the Premier Kosygin in 1968. The Soviet promised for assistance in many Pakistani projects and later, built Pakistan Steel Mill at Karachi. It was also because of the growing Sino-Pakistan entente (Rajput, 1973).

It was natural for China to express her surprise on the new bilateral relationship between Pakistan and Soviet Union and called it superpowers' conspiracy. After the conclusion of the Tashkent Declaration, on 11 January 1966 NCNA stated the declaration's ineffectiveness to reach on the solution of the Kashmir problem and Pakistan's dissatisfaction with the whole process. Later, on 10 April, Peking branded the declaration as a "product of U.S.-Soviet conspiracy". Chen on a visit to East Pakistan in mid-April remarked against the previous USSR's statements about China's support for Pakistan against India. He said that Soviet Union had provided large amount of weapons to the "aggressor" (India) and backed the Indian "annexation" of Kashmir. Chen described the Soviet as "an imperial mediator" (Simon, 1967)

Peking believed that the Tashkent Declaration was a united "US-Soviet-Indian conspiracy" against a victim Pakistan. At a banquet for a visiting Pakistani Commerce Minister Ghulam Faruque in April and July, Chen reassured Pakistan that China would come to help its friend in case of "an armed attack of any aggressor". On the going closer of Pakistan to the Soviet, a Chinese official reproved gently to the visiting of former's guests: "There are true friends and false friends, but one can see in practice clearly who are true friends and false ones". At a Pakistani Friendship delegation banquet in October and upon the visit of the then Pakistan's Foreign Minister, Sharifuddin Pirzada, Chen again stated his above-stated words. To review the US-Soviet "collusion" during 1966, NCNA described the Tashkent Declaration as a joint attempt of the United States and the Soviet Union "to produce a 'Tashkent declaration' partial to India, so as to draw that country further into their ranks of hostility to China" (Ibid., p. 186). Pakistan replied China for her generous support by supporting the Beijing's representation in the United Nations. "As a token of good faith towards China, however, it is noteworthy that Pakistan co-sponsored at 18 November resolution calling for the seating of the CPR in the United Nations and the expulsion of the Chiang Kai-shek regime" (Ibid.).

The Pakistan's aspirations for good relations with the Soviet Union came at a time when China had border clashes with the USSR at the end of 1960s. These developments resulted in doubts in Chinese minds about the Soviet-Pakistan relations that Soviet Union and United States might bring a common front with India and Pakistan against PRC.

\section{Sino-American Rapprochement}

While answering the journalists' questions, Richard Nixon was hopeful about the Sino-US rapprochement. He said: "The long-range goal of this administration and of the next one - whatever it may be, must be two things: one, a normalization of the relations between the Government of the United States and the Government of the People's Republic of China, and two, the ending of the isolation of Mainland China from the world community" (American Society of Newspaper Editors, 1971). Although the problem of lack of openness in China can illustrate the process of her relations with the US in incomplete way, but the desire for normalization of relations was from both sides. According to William Burr "the U.S. documentation represents only a partial record of a complex relationship. While Chinese archival sources are largely unavailable" (Burr, 2002). For decades the Sino-US relationship had been frozen by mutual hostilities, for the US largely in ideological and for China, in survival frameworks. Actually the representative of the People's Republic of China had showed willingness about the reception in Peking of the "U.S. representative of Ministerial rank or a special Presidential envoy" at the Warsaw meeting of 20 February 1970 (US National Security Archive, 1970). The normalization of relations between China and the United States took place in February 1972 when the American President Richard Nixon met with Chinese Chairman Mao Zedong in P.R. China. Their détente is considered to be an influencing event in the twentieth century. Such a major happening was affected by many factors. For China; its continued disputes with the Soviet Union, potentially the Japanese rise, Chinese 
self-confidence, Zhou En-lai's succession in preserving the Foreign Ministry, reduced fear of the United States in the form of "recession of U.S. power from the Pacific and steady withdrawal from the South Vietnam under the Nixon administration" paved a way for China's normalization of relations with the US (Overholt, 1973).

During the period, Sino-Soviet relations were at low ebb. China was not only in struggle with the Soviet for International Communism and supporting the Afro-Asian-Latin American countries for their just cause of freedom in all forms, but also had bloody clashes with her on its longest land border. This was a reversing process of the Soviet Union during the Khrushchev's administration when the Kremlin had contacts with the White House. Through the prism of its memory, the isolated Beijing viewed the Japanese rise as a threat. Indeed the rapprochement with the US was a severe blow for the America's ally in the region. The China was more confident as compare to 1949 to take a bold step. The United States' commitment for withdrawal of its troops from the South Vietnam was greatly detrimental in mid of devastating Cultural Revolution. Nixon was realizing the weakening positions of SEATO and CENTO which were mainly for the containment of communist states of PRC and USSR, China hoped for the US' negotiations on Taiwan. For United States; "Vietnam, domestic social issues, the rapid rise of Russian military power, and erosion of allied support for the U.S. policy of isolating China" and the American public insistence "for change in China's policy" resulted in normalization with China (Ibid., 708).

\subsection{Pakistan's Role}

Now here is the question to answer:

How did Pakistan play a role in the Sino-American détente?

The United States was trying not to communicate with Red China directly, but through a channel. She had two good options, one through Romania and second through Pakistan. President Nixon discussed the Chinese matter with the Romanian President Nicolae Ceausescu. But the problem was Soviet Union with whom Romania had good relations. According to Dr. Kissinger "just in case this conversation should reach Soviet ears - not improbable - Nixon waxed eloquent about his desire for good relations with both China and the Soviet Union" (Kissinger, 2000). Being a formal ally of the US and informal ally of the PRC, Pakistan was a best choice to act as a bridge between United States and China. America gave this task to Islamabad. The Then Pakistan's President General Yahya Khan visited the US to celebrate the $25^{\text {th }}$ anniversary of the United Nations. It was the time when the US was trying to reproach China. President Nixon met with President Yahya at the Oval Office on 25 October, 1970 and asked the Pakistani President for conveying a Washington's message to Beijing (Ibid.). Nixon started conversation by assuring his friendship to Pakistan and reminded "the hundred million dollar program loan of AID". Yahya thanked Nixon and vowed for continuation of friendship. Yahya stated that Zhou En-lai had promised him to visit Pakistan before any county's trip but unfortunately he went to North Korea and thus apologized to him. So, invited Yahya to Peking, Nixon said: "It is essential that we open negotiations with China. Whatever our relations with the USSR or what announcements are made I want you to know the following: (1) we will make no condominium against China and we want them to know it whatever may be put out; (2) we will be glad to send Murphy or Dewey (as envoy) to Peking and to establish links secretly" (US National Security Archive, 1970).

Yahya further said that he had already told to Chinese leaders and they were thinking that the United States might want a hot line same with that was established with Moscow. Nixon stated no, the US wanted to send ambassadors. Kissinger interrupted by saying that the US wanted the secret communication and thinking a convenient capital like Rawalpindi or Paris. Yahya assured them that "he would explain this to the Chinese" (US National Security Archive, 1970). It is evident from the discussion that Washington was looking for a state-head to convey his message to Beijing. He reminded the US' assistance for Pakistan and promised for more aid. In the case of difficulty for Chinese to negotiate in Beijing, the US was confident about the utility of Rawalpindi as a table place. United States mentioned about the Soviet Union that whatever the results, she was willing to have contact with Beijing. To halt the Soviet way, a balance of power among the US-Pakistan-PRC had to be established.

China acknowledged later the Pakistan's efforts for China's normalization of relations with United States. Zhou En-lai remarked: "We have had messages from the United States from different sources in the past but this is the first time that proposal has come from a Head, through a Head, to a Head. The United States knows that Pakistan is a great friend of China and therefore we attach importance to the message" (US National Security Archive, 1970).

Zhou expressed his warm feelings for Pakistan that Beijing had already received messages from Washington through different sources. But the importance of this message was that it had come from Nixon, through Yahya, to Mao and an appreciation was present for Pakistan as a "great friend of China".

Yahya Khan then paid a visit to Peking in November 1970. The next day after his arrival, Yahya had one to one meeting at the Old French Embassy in Beijing. Yahya conveyed the Nixon's message of sending ambassador to Zhou. After 
consulting with Chairman Mao, the next day Zhou replied to Yahya that PRC accepted the proposal to receive the envoy of Nixon to Peking. He added that China had attached importance to the message given by Pakistan (Khan, 2014). The importance given to Pakistan by China was evident from the fact that the Yahya Khan's visit was one of the "colorful", "festive" and "enthusiastic" welcomes given to any head of state. Zhou and other senior members of the Communist party received their guest and there was a huge crowd singing, dancing and waving the two countries' flags (Ibid.).

China showed its happiness over the visit of a Pakistani Head and as before, this time too extended assistance for the latter as a gesture of good-well. "The trip was marked by some other events of great significance like China wrote off all the financial debts owed by Pakistan up to that date. China also signed an agreement with Pakistan for further military supplies, and Yahya Khan had every reason to be very happy and pleased with the visit" (Ibid.).

In the aftermath of the President Yahya's trip to Peking, the Nixon Administration had to discuss the further matters. Zhou En-lai had sent a willing message to Nixon about the representatives' talks and Henry Kissinger had conveyed it to President on $9^{\text {th }}$ December 1970.

\section{Conclusion}

Looking to the regional security scenario, China had cordial relations with only one country in South Asia, Pakistan, important in the respect that both had disputes with India. The Red China's hostilities and suspicions with both superpowers were further deteriorating the situation. The domestic set up of China was also shakable in the wake of 'Great Proletarian Cultural Revolution'. If Pakistan could become cordial with the Soviet, China could totally isolate in the region; that of China's southward. Instead of accusing Pakistan, like before, China stated these developments as a game of conspiracy among the Soviet, US and India. But once again, later proved by the strong Sino-Pakistan ties that positive trend prevailed over the negative one. On the other hand, being an ally of the US and friend of China, Pakistan helped China and United States to normalize their bilateral relationship.

\section{References}

American Society of Newspaper Editors. (1971). National Security Archive's Electronic Briefing Book No.66, Document 15, The President's Remarks at a Question and Answer Session With a panel of Six Editors and Reporters at The Society's Annual Convention. http://www.gwu.edu/ nsarchiv/NSAEBB/NSAEBB66/ch-15.pdf

Ashraf, T. M. (2008). Sino-Pakistani Defense Relations and the War on Terrorism. Terrorism Monitor, 6(8).

Barnds, W. J. (1972). India, Pakistan and the Great Powers. New York: Praeger Publishers.

Barnds, W. J. (1975). China's Relations with Pakistan: Durability amidst Discontinuity. The China Quarterly, 63, 463-476. http://dx.doi.org/10.1017/S030574100000727X

Bhutto, Z. A. (1972). Bhutto in 1969. Pakistan Forum, 2(7/8), 5-6

Burr, W. (2002). Negotiating U.S.-Chinese Rapprochement, National Security Archive Electronic Briefing Book No. http://www.gwu.edu/ nsarchiv/NSAEBB/NSAEBB70/\#III

Das, T. (1972). Sino-Pak Collusion and US Policy. Bombay: Asia Publishing House.

Duffy, A. E. P. (1967). The Present Viability of NATO, SEATO and CENTO. Annals of the American Academy of Political and Social Science, Realignments in the Communist and Western Worlds, 372(38). http://www.jamestown.org/programs/gta/single/?tx_ttnews[tt_news]=4862\&tx_ttnews[backPid]=167\&no_cache=1 http://dx.doi.org/10.1177/000271626737200104

Kapur, A. (1970). Peace and Power in India's Nuclear Policy. Asian Survey, 10(9), 779-788. http://dx.doi.org/10.2307/2643029

Kapur, A. (1972). Indo-Soviet Treaty and the Emerging Asian Balance. Asian Survey, 12 (6), 463-474. http://dx.doi.org/10.2307/2643044

Kemenade, W. V. (2008). The Fragile Pakistani State: Ally of the United States and China, 8-9. www.clingendael.nl/publications/2008/20080300_cdsp_paper_kemenade.pdf

Khan, S. M. (2014). Foreign Secretary of Pakistan, Yahya Khan's Visit to Beijing. http://www.pbs.org/wgbh/amex/china/filmmore/reference/interview/khan02.html

Kissinger, H. (2000). White House Years. New Haven: Phoenix Press.

Mukerjee, D. (1968). India's Defence Perspectives. International Affairs, 44(4), 666. http://dx.doi.org/10.2307/2614923

Overholt, W. H. (1973). President Nixon's Trip to China and Its Consequences. Asian Survey, 13(7), 708-709. http://dx.doi.org/10.2307/2642707 
Paul, T.V. (1992). Influence through Arms Transfers: Lessons from the U.S.-Pakistani Relationship. Asian Survey, 32(12), 1078-1092. http://dx.doi.org/10.2307/2645039

Rajput, M. A. (1973). Soviet-Pakistan Relations. Pakistan Forum, 3(12), 3-7. http://dx.doi.org/10.2307/2569058

Ram, M. (1978). Karakoram Highway. Economic and Political Weekly, 13(26), 1058

Simon, S. W. (1967). The Kashmir Dispute in Sino-Soviet Perspective. Asian Survey, 7(3), $176-187$. http://dx.doi.org/10.2307/2642236

Singh, G. (1987). Sino-Pakistan Relations: The Ayub Era. Amritsar: Gurunanak Dev University Press

Singh, S. (1999). Sino-Pak Defence Co-operation: Joint Ventures \& Weapons Procurement. Peace Initiatives, V (III-VI), 1-15

Stein, A. (1967). India and the USSR: The Post-Nehru Period. Asian Survey, 7(3), 165-175. http://dx.doi.org/10.2307/2642235

US National Security Archive. (1970). Electronic Briefing Book No.66, Document 6, Chinese Communist Initiative. http://www.gwu.edu/ nsarchiv/NSAEBB/NSAEBB66/ch-06.pdf

US National Security Archive. (1970). Electronic Breifing Book No. 66, Document 8, MEMORANDUM OF RECORD. http://www.gwu.edu/ nsarchiv/NSAEBB/NSAEBB66/ch-08.pdf

US National Security Archive. (1970). Electronic Briefing Book No.66, Document 3, Meeting Between the President (Nixon) and President Yahya. The Oval Office. http://www.gwu.edu/ nsarchiv/NSAEBB/NSAEBB66/ch-03.pdf

Wriggins, W. H. (1970). The Presence in Southern Asia of outside Powers. Annals of the American Academy of Political and Social Science, A New American Posture toward Asia, 390, 48-61. http://dx.doi.org/10.1177/000271627039000106

\section{(cc) EY}

This work is licensed under a Creative Commons Attribution 3.0 License. 